E3S Web of Conferences 1, 41036 (2013)

DOI: $10.1051 / \mathrm{e} 3$ sconf/ 20130141036

(C) Owned by the authors, published by EDP Sciences, 2014

\title{
Health Assessment of Mercury Exposure in a Riparian Community in the Madeira River
}

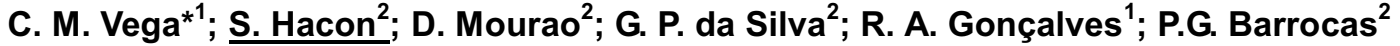 \\ ${ }^{1}$ Departamento de Quimica, Universidade Pontificia Catolica do Rio de Janeiro, Rua Marquês São \\ Vicente, 225, Gávea Rio de Janeiro - RJ, 22451-041. \\ 2 Escola Nacional De Saude Publica, Fundação Oswaldo Cruz, Rua Leopoldo Bulhões, 1480 .Manguinhos, \\ Rio de Janeiro - RJ, 21041-210
}

\begin{abstract}
Mercury concentrations were analyzed in a riparian community from the Cuniã Lake RESEX (a riparian extrativist reserve) at the Madeira river, located in the Amazon region. The studied population age ranged from 2 to 90 years old and hair was used as biomarker. A total of 252 hair samples were collected from fishermen families. $\mathrm{Hg}$ concentrations averaged 6.0 (IC95\% 5.58-6.58) $\pm 3.9 \mu \mathrm{g} \cdot \mathrm{g}^{-1}$ (SD). The fish consumption for adults in this community ranges from 40 to 600 grams per day. The results showed significant gender differences for $\mathrm{Hg}$ levels ( $\mathrm{p}$-value $<0.05$ ); for male individuals the average was 7.4 (IC 95\% 5.56-8.28) $\pm 4,5 \mu \mathrm{g} . \mathrm{g}^{-1}$ and for female individuals was of 5.0 (IC 95\% 4.49-5.54) $\pm 3.3 \mu \mathrm{g}^{-\mathrm{g}^{-1}}$. Studies on neurological symptoms and diet of this community are under way along with other clinical trials and biochemical measurements.
\end{abstract}

Keywords: Mercury, fish, hair-Hg, riparian, Amazon

\section{Introduction}

Mercury is a global pollutant whose potential toxicity varies according to its different chemical forms. It is known that due to bioaccumulation and biomagnification, elevated $\mathrm{Hg}$ values can be detected in high trophic levels. Consequently, a fish based diet is considered the primary pathway of human exposure to methyl-Hg (Pfeiffer, 1991; Malm, 1995; Bastos, 2006; Megler et al., 2007). This is of special concern in the Amazon region (Barbieri \& Gardon 2009; Bastos, 2006; Pinheiro, 2005; Campos, et al. 2002; Dolbec, et al. 2001; Harada 2001). The scenario of human mercury exposure in the Amazon has changed as gold extraction has diminished and a decrease in human hair mercury concentrations in the last decade has been observed (Barbieri and Gardon 2009). However, it is important to understand that the Amazon basin represents a natural laboratory for studying the effects of low mercury exposure. The interactions with diet, clinical history, and susceptibility to endemic disease mechanisms still remain unclear. The complexity of the Amazonian ecosystem and the limited knowledge of mercury's biogeochemical cycle in tropical rain forests explain the difficulties faced by the scientific community in assessing the impact of mercury contamination. These issues affect the potential for exposure of the local populations and, consequently, the risk involved. High mercury levels in fish have been reported in sites close to gold mining (where mercury was extensively used), as well as in areas with no history of such activity.

The present work is part of a program of Health Risk Assessment of $\mathrm{Hg}$ in a riparian extrativist reserve at the Cuniã lake. This area will be under indirect impact of a hydroelectric power construction as a consequence of the new economic profile of this region. Fishing is the main activity of this community, and there is no history of gold extraction in the area. Fish is their main protein source, eventually complemented with caiman meat and water birds.

\section{Materials and Methods}

The study site is located at the Cuniã Lake RESEX (Riparian Extrativist reserve), located $200 \mathrm{Km}$ from Porto Velho, the capital of Rondônia. Is an area of $50 \mathrm{~km}^{2}$ at the left margin of the Madeira river (tributary of the Amazon River) and downstream of the Santo Antonio hydroelectrical power plant construction (Figland 2).

An interview administered questionaire and georeference census were conducted by paticipatorial approach between October 2010 and June 2011, and 249 human hair samples were collected 
Figures 1 and 2 show the location of the Cuniã Lake RESSEX.
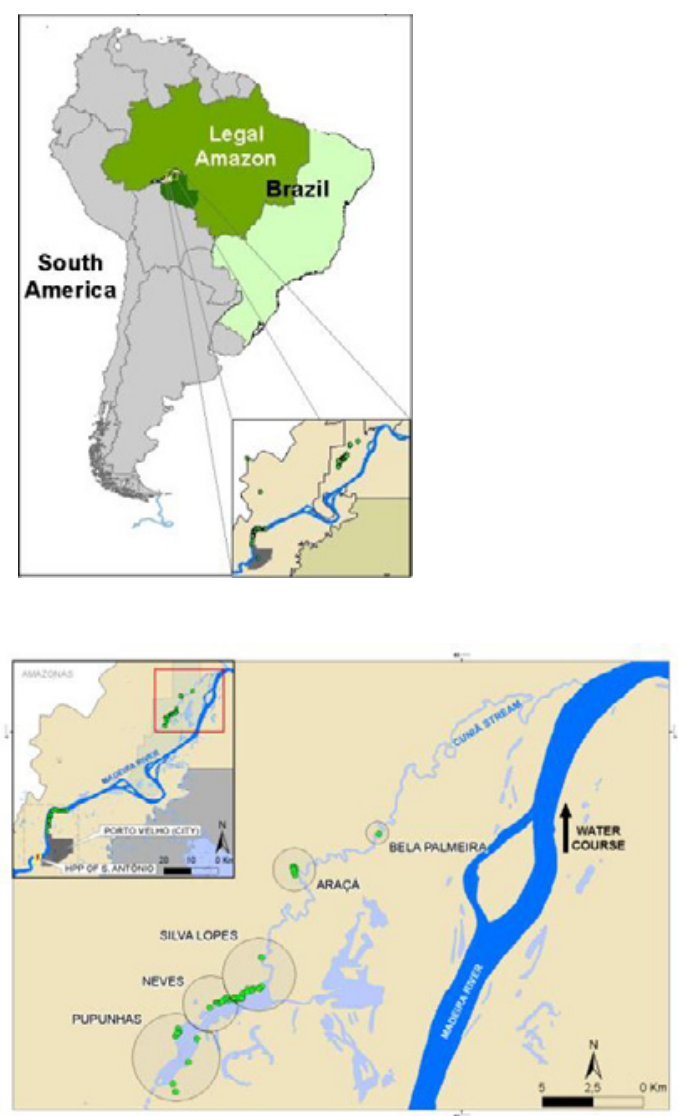

Fig1 and 2 Location of the Cuniã RESEX

\section{Mercury Determination}

For $\mathrm{Hg}$ determination, an acid digestion at high temperature $\left(80^{\circ} \mathrm{C}\right)$ was applied (Campos, 1988), followed by the analysis of the sample solution by the cold vapor generation technique in a MHS 10 CV Model 3300 AAS (Perkin Elmer.) Quality control was performed by strict blank control and the analyses of replicates and reference material. Accuracy was assessed by analysis of certified material CRM 13 human (Hair Reference material). The recovery rate was always above $95 \%$.

\section{Results and Discussion}

The Cuniã lake RESEX is a community made up of 66 families, 251 inhabitants and the population age range is between 2 to 90 years old. Fishing is the main activity of this community, and there is no history of gold extraction. Fish is their main protein source; $58 \%$ of the community eat fish every day; $21 \%$ more than 3 days a week; $19 \%$ eat fish 1 or 3 days a week and only $2 \%$ eat this source of protein every 15 days. Some people eventually complement their protein source with caiman and bird meat.

As mentioned previously, $\mathrm{Hg}$ bioacumulates and biomagnifies throughout the food chain, and higher trofic levels are expected to have higher mercury concentrations. The following figure shows the type of fish consumed at the Cuniã Lake RESEX.

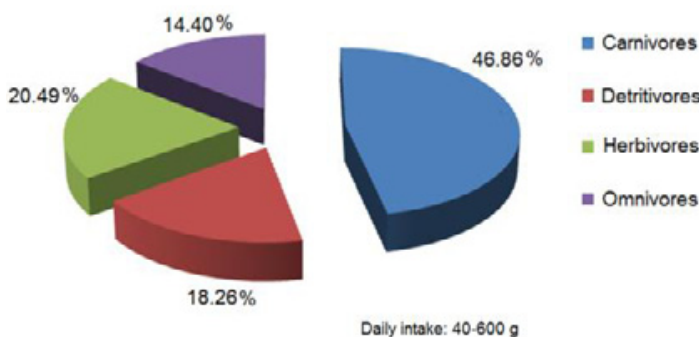

Fig 3. Type of fish consumed at the Cuniã Lake RESEX

A positive relationship between fish consumption and mercury levels in hair was observed (Fig 4), and this association was more significant $(0.05$ level, 2-tailed) when the population was divided into two classes: adults $(<15$ years old) and children ( $\geq 15$ years old) (Fig 5$)$. This observation reinforces what other authors report regarding fish consumption as one of the main sources of $\mathrm{Hg}$ exposure (Pfeiffer, 1991; Malm, 1995; Bastos, 2006; Megler et al., 2007).

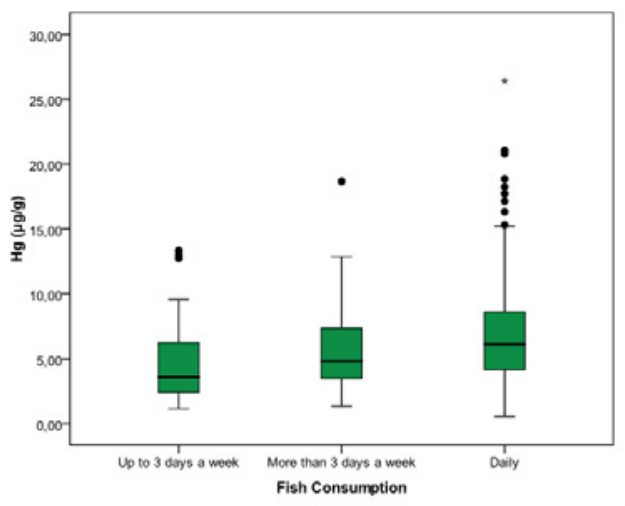

Fig 4. Relationship between fish consumption and Hair-Hg levels 


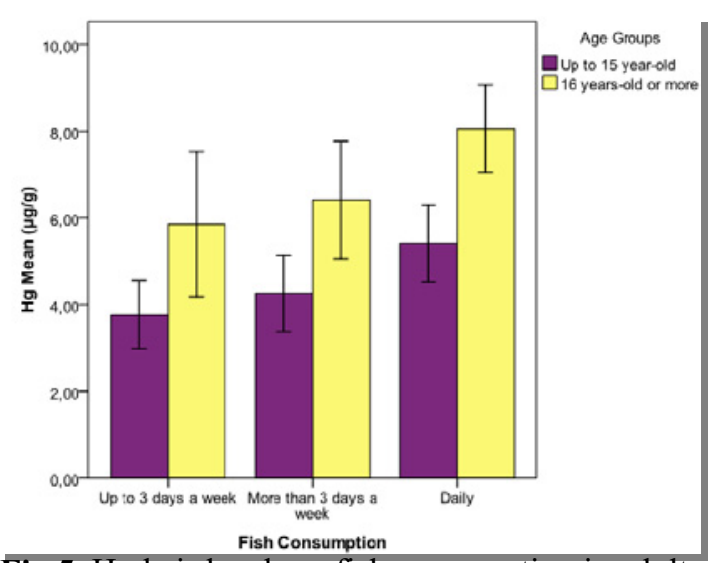

Fig 5. Hg hair levels vs fish consumption in adults and children at the RESEX Cuniã lake

$\mathrm{Hg}$ levels in the hair samples presented a mean of $7.6 \pm 5 \mu \mathrm{g} \mathrm{g}^{-1}$ dry weight with maximum value of $33.7 \mu \mathrm{g} \mathrm{g}^{-1}$ and minimum of $0.4 \mu \mathrm{g}$ $\mathrm{g}^{-1}$. Table 1 presents the $\mathrm{Hg}$ level distribution by sex. The mean levels of $\mathrm{Hg}$ in men were significantly higher than in women $(p<0.05)$.

Table1: Mercury Hair Levels at Cuniã Lake

\begin{tabular}{|c|c|c|c|c|c|c|}
\multicolumn{8}{c|}{ RESEX $\left(\mu \mathrm{g} \mathrm{g}{ }^{-1}\right.$ d.w. $)$} \\
\hline Gender & Mean & N & St. Dev. & Median & Min & Max \\
\hline Male & 9.7 & 114 & 5.8 & 8.9 & 0.4 & 33.7 \\
Female & 5.9 & 135 & 3.6 & 5.3 & 0.7 & 18.9 \\
\hline Total & 7.6 & 249 & 5 & 6.3 & 0.4 & 33.7 \\
\hline
\end{tabular}

It was observed that $23 \%$ of the total population showed total mercury hair levels above the WHO reference dose $\left(10 \mu \mathrm{g} \cdot \mathrm{g}^{-1}\right)$. However, the WHO limit is based on acute exposure events. The case at Cuniã, however, is chronic exposure to low $\mathrm{Hg}$ doses by food ingestion (fish). There is a lack of information about the effects of low chronic exposure of mercury in humans, and these are still undefined.

No evident abnormalities were observed in the neurological tests applied to children. However, schoolteachers have complained complain about student vision problems, making it important to evaluate vision impairment at this community. Blood pressure showed a significant positive association with $\mathrm{Hg}$ hair levels only in the group composed of adult me, however this association was weak and not observed in other groups.
Correlations between blood pressure and $\mathrm{Hg}$ Hair Levels at Cuniã RESEX

\begin{tabular}{|l|c|c|c|c|}
\hline \multicolumn{4}{|c}{ Male } & \multicolumn{2}{c|}{ Female } \\
\multicolumn{1}{|c|}{ Adults } & \multicolumn{1}{c}{ Children } & Adults & Children \\
\hline $\begin{array}{l}\text { Sistolic } \\
\text { Pressure }\end{array}$ & $0.262^{*}$ & 0.145 & 0.078 & 0.007 \\
\hline $\begin{array}{l}\text { Diastolic } \\
\text { Pressure }\end{array}$ & $0.282^{*}$ & 0.128 & -0.004 & -0.049 \\
\hline \multicolumn{5}{|c|}{${ }^{*}$ significant at 0.05 level (2-tailed) } \\
\hline
\end{tabular}

\section{Conclusion}

Carnivore fish (that present higher $\mathrm{Hg}$ levels) are the most frequently consumed and, therefore, could increase the risk of $\mathrm{Hg}$ exposure in the population, mainly in women at a reproductive age.

These areas are important to monitor since anthropic activities, such as the construction of hydroelectric plants, may be affecting the ecosystem.

\section{Acknowledgements}

To CAPES and INOVA-ENSP for the financial support.

\section{References}

Bastos WR, Gomes JP, Oliveira RC, et al. Mercury in the environment and Riverside population in the Madeira River Basin, Amazon, Brazil. SciTot Env 3006; 368:344-351.

Barbier FL. Gardon J. Hair Mercury levels in Amazonian populations: Spatial distribution and trends. International Journal of Health Geographics 2009, 8: 71

Clarkson TW, Magos L. The toxicology of mercury and its chemical compounds. Crit Ver Toxicol 2006;36(8):609-20.

Campos R. C. Estudo da Determinação de Mercúrio por Espectrometria de Absorção Atômica pela Técnica do Vapor Frio Dissertação de Mestrado. Pontifícia Universidade Católica do Rio de Janeiro 1988;

Campos MS, Souza JE, Sarkis RC, et al. Correlation between mercury and selenium concentrations in Indian fair from Rondônia State, Amazon region, Brazil. Sci Total Environ 2002: 287: 155-161.

Dolbec J, Megler D, Larribe et al. Sequential analysis of hair mercury levels in relation to fish diet of an Amazonian population, Brazil. Sci Total Environ 2001:271:87-97.

Hacon S, Barrocas PG, Vasconcellos AC, et al An 
overview of mercury contamination research in the Amazon basin with an emphasis on Brazil. Cad Saúde Pública 2008; 24(7):1479-92.

Harada M. Nakanishi J. Yasoda E, et al. Mercury pollution in the Tapajos River basin, Amazon Mercury level of head hair and health effects. Enviroment International 27(2001) 285- 290.

Malm O, Branches FJP, Akagi H, et al Mercury and Methylmercury in fish and human hair from the Tapajos river basin, Brasil. Sci Total Environ 1995; 175: 141-50.

Pinhero MCN. Mercury and Selenium concentrations in hair samples of women in fertile age from Amazon riverside communities. Science of the Total environment. 2005; 349: 284-286. 